\title{
Neurosurgical Videos on YouTube
}

\section{Vídeos Neurocirúrgicos no YouTube}

\author{
Julio Leonardo Barbosa Pereira ${ }^{1}$ Felipe Batalini ${ }^{2}$ Pieter L. Kubben ${ }^{3}$ \\ Lucas Alverne Freitas de Albuquerque ${ }^{1}$ Bernardo Andrada ${ }^{4}$ Pollyana Magalhães ${ }^{1}$ \\ Gervásio Teles C. de Carvalho ${ }^{1}$ Eberval Gadelha Figueiredo ${ }^{5}$
}

${ }^{1}$ Department of Neurosurgery, Santa Casa de Belo Horizonte, Belo
Horizonte, MG, Brazil
${ }^{2}$ Associação de Combate ao Câncer em Goiás, Goiás, GO, Brazil
${ }^{3}$ Department of Neurosurgery, Medicine and Life Sciences Education,
Maastricht University Medical Center, Maastricht, The Netherlands
${ }^{4}$ Hospital Estadual Getúlio Vargas, Rio de Janeiro, RJ, Brazil
${ }^{5}$ Department of Neurosurgery, Universidade de São Paulo, SP, Brazil

Address for correspondence Felipe Batalini, MD, Rua Jose Lorenceti, 120, Presidente Prudente, SP, Brazil, CEP: 19050-350

(e-mail: batalinimd@gmail.com).

Arq Bras Neurocir 2016;35:13-17.

\section{Abstract \\ Keywords \\ - e-learning \\ - youtube \\ - instructional videos \\ - internet \\ - neurosurgery \\ - education}

\section{Resumo}

Palavras-chave

- e-learning

- YouTube

- vídeos instrucionais

- internet

- neurocirurgia

- educação
Introduction Videos can become valuable teaching tools and YouTube is a useful tool to disseminate information. It was created in February, 2005; since then, there has been a rapid expansion of YouTube videos on several subjects. Neurosurgery is not an exception in this trend, and several channels on the topic are available at the YouTube website.

Methods We analyzed many articles related to the theme in several medicine specialties. In this study, we balance the pros and cons of this new technology, to foster a discussion of these changes, as well as to explain how to create and get the most from it. We also list some interesting channels and their features as examples and suggestions.

Results YouTube should be the main platform for supporting instructional videos, although it is important to be cautious at this time, as the platform still lacks good quality videos.

Conclusion This technology could turn into a very important tool for learning and teaching neurosurgery. Educational institutions should guide an effort for better quality videos and broader content coverage, which could also achieve superior training at no cost.

Introdução Vídeos podem tornar-se ferramentas de ensino valiosas e o YouTube é uma plataforma muito útil para a disseminação da informação. Desde sua criação em fevereiro de 2005, houve grande expansão na quantidade dos vídeos de vários conteúdos e a neurocirurgia não está fora dessa onda, muitos canais relacionados podem ser encontrados no YouTube.

Métodos Analisamos artigos relacionados ao tema em várias especialidades médicas. Balanceamos prós e contras dessa nova tecnologia, estimulamos a discussão dessas mudanças e ainda explicamos como criar e ter máximo proveito. Alguns canais interessantes são também listas como exemplos e sugestões. received

June 8,2014

accepted

August 7, 2015

published online

September 25, 2015
DOI http://dx.doi.org/

10.1055/s-0035-1564419. ISSN 0103-5355.
Copyright $\odot 2016$ by Thieme Publicações License terms

Ltda, Rio de Janeiro, Brazil
(요 $\Theta \circledast$ 
Resultados O YouTube deve ser a principal plataforma para vídeos instrucionais, mas nesse momento o conteúdo deve ser tomado com cuidado, uma vez que há ainda escassez de vídeos de boa qualidade.

Conclusão Essa tecnologia pode tornar-se importante ferramenta na aprendizagem e ensino da neurocirurgia. Um esforço para vídeos de boa qualidade e maior abrangência de conteúdo deveria ser guiado por instituições de ensino, que também podem conseguir treinamentos melhores e mais baratos.

\section{Introduction}

Neurosurgical movies on YouTube are a fast-growing trend. There are multiple YouTube channels about neurosurgery and it is not limited to the contents of surgeries but it is also common to find lectures, courses and conferences being shared.

Health professionals' awareness of the usefulness of these new tools is increasing and their participation in the material released grows daily. ${ }^{1}$

The digital era has been characterized by widespread access to information, opening a new era in medicine, with a profound change in the way we learn and teach. ${ }^{2-6}$ A recent study showed a faster learning curve for spinal surgery for residents participating in a video-based training program, and the learning plateau was achieved in half the time it would take with regular training, without the systematic use of videos. ${ }^{2}$

\section{Neurosurgery Videos}

Neurosurgery is a field of Medicine in which learning surgical techniques require acute observation of procedures repeatedly, laboratory training and subsequent application of the acquired knowledge. Observation and technique application should be performed in a systematic way. ${ }^{5}$ Often these procedures are very time-consuming and do not integrate everyday practice which would enable online videos to become valuable educational materials.

In this article, we give special emphasis to YouTube, which enables the sharing of surgical videos performed anywhere in the world. For reasons such as the very low cost, technical simplification, and reaching capacity, YouTube should be considered the main platform for diffusing educational videos on the Internet. ${ }^{7,8}$

Like any free educational material online, YouTube enabled an even greater impact in developing countries, where the cost of constant update courses, conferences and access to skull base laboratories is often prohibitive. The Internet has provided the tools that allow a much more democratic access to up-to-date neurosurgical content. ${ }^{4,7-9}$

The aim of this paper is to provide a brief discussion about available neurosurgical YouTube videos, to describe the functions of a YouTube Channel, to explain how to create a YouTube channel, and, finally, list some useful channels in the neurosurgery field and its characteristics.

\section{Video Quality}

Some authors show the positive impact of YouTube videos in medical education. ${ }^{3,10,11}$ However, although there are useful and good-quality videos, most of them are not, which requires that the viewer be very selective. ${ }^{1,8,10,12-17}$

Rossler found that only $14 \%$ of videos regarding lumbar puncture and spinal anesthesia are of good quality. ${ }^{15}$ These procedures, despite being important, are not among the most complex. Thus, it is possible to infer that the rate of good videos can be even lower if we evaluate procedures that require more ability and training. However, this hypothesis require further investigation.

\section{YouTube}

YouTube is a video-sharing website, created in February 2005, through which users can upload, view and share videos. Almost 60 hours of new videos are uploaded to the site every minute, and around three quarters of the material comes from outside the United States. ${ }^{13}$ The site has 800 million users a month. It ranks third in most visited website on the internet, surpassed only by Google and Facebook. ${ }^{13}$

YouTube is a tool that provides people who do not have specific knowledge in film editing the possibility to put content on Internet, with a very low difficulty level. It also allows them to create a network for sharing those videos, information and opinions. After its creation, there was a boom in the number of YouTube channels with a big variety of neurological surgery topics on the internet. ${ }^{13}$

It also proved to be useful in patient education, but this idea must still be taken with care. ${ }^{18}$ In fact, Azer shows that YouTube is currently an inadequate source of information for learning surface anatomy. ${ }^{13}$ However, Topps et al. show that YouTube's broadcast model diffuses aspects of the relationship between educators and their learners for more focused activities, such as continuing medical education. ${ }^{7}$

It is also important to note that students felt they had learned more with the addition of YouTube videos to their course content. ${ }^{3}$

To optimize the educational use of YouTube, it is necessary to know the main neurosurgery channels (-Table 1). It is possible to subscribe to these channels. The subscription service allows the server to send personal emails whenever there is new content available. Readers can comment after 
Table 1 Examples of YouTube channels on Neurosurgery

\begin{tabular}{|l|l|l|l|l|}
\hline Channel & Link & Views & Followers & Videos \\
\hline Neurosurgery Blog & www.youtube.com/neurocirurgiabr & $>91,000$ & $>610$ & 100 \\
\hline Neurosurgery Journal & www.youtube.com/neurosurgeryCNS & $>371,000$ & $>1,360$ & 196 \\
\hline AANS Neurosurgery & www.youtube.com/AANSneurosurgery & $>326,000$ & $>3,010$ & 124 \\
\hline
\end{tabular}

seeing the videos, as well as "like" and share them. Many of these channels organize and select surgical videos made by neurosurgery masters.

\section{YouTube Channels}

The American Association of Neurological Surgeons (AANS) has a channel of videos on neurosurgical procedures, with some lectures and courses. There are very useful lectures from Dr. Rhoton about 2D and 3D neuroanatomy (-Fig. 1).

The Neurosurgery Channel is related to the magazine and Neurosurgery CNS. This channel has several neurosurgical procedures as well as some lectures (-Fig. 2).

The Neurosurgery Blog, created by Pereira JLB, releases videos from Santa Casa de Belo Horizonte, Brazil. It shares surgeries, some neuroanatomy classes and information for patients. Part of the process of their resident training is the critical analysis of the procedures, which required the surgeries to be recorded, which led to the creation of the channel with the primary purpose of sharing knowledge for educational purposes (-Fig. 3 )

\section{How to Create a YouTube Channel}

The process of creating a YouTube channel is very simple and self-explanatory, all that is needed is to choose a theme (layout) and fill out basic information about the content of the channel. Next, one simply posts their video by uploading it. The process of building a YouTube channel is in itself a learning opportunity and an interesting part of the process.

Some legal aspects are important. Depending on the country in which the video was recorded, required authorizations may vary. Some cautions are universal, such as nonidentification of the patient in the case of surgical videos, and, in the case of classes, it is obviously necessary to have permission from its author. It is important to remember that videos are subject to copyright, as any educational production.

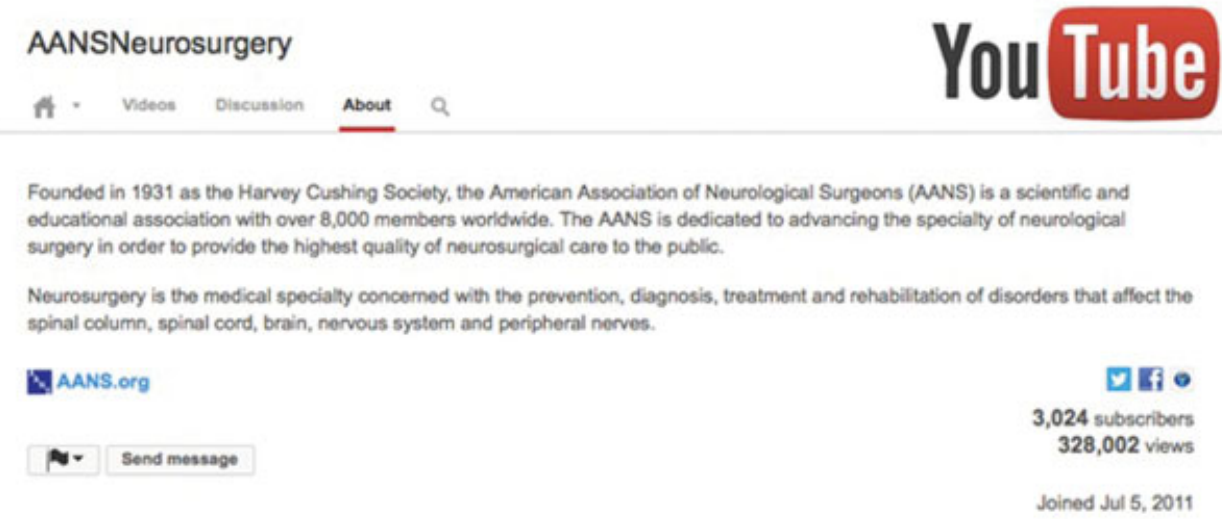

Fig. 1 AANS Neurosurgery.

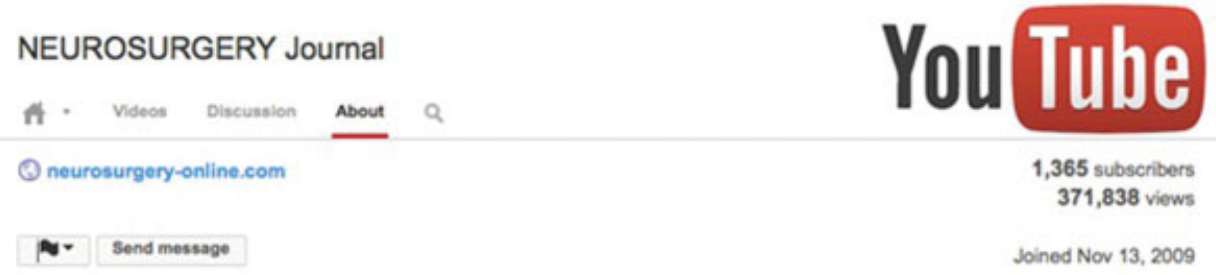

Fig. 2 Neurosurgery Journal. 


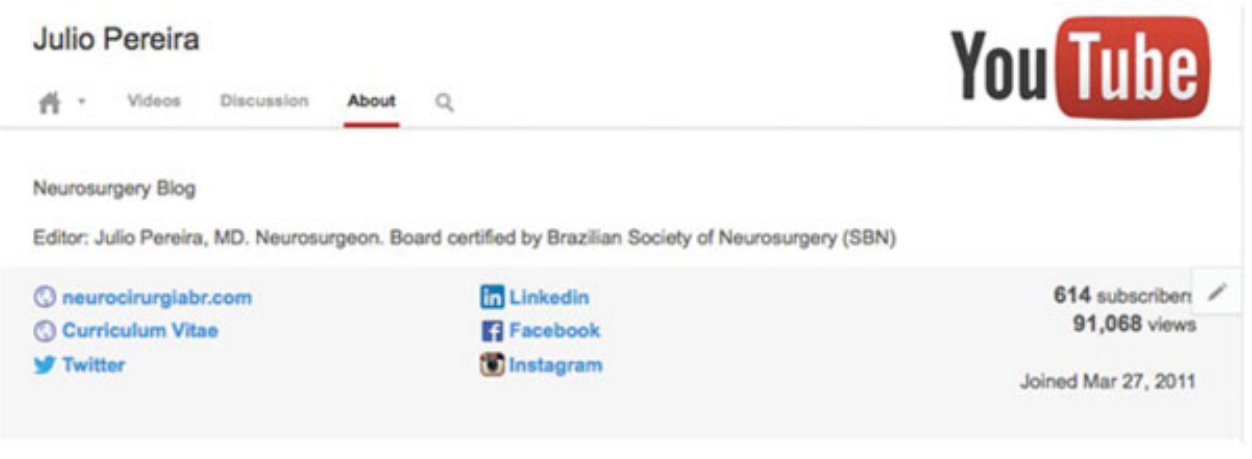

Fig. 3 Neurosurgery Blog.

\section{Discussion and Final Considerations}

YouTube is an important platform for sharing information that could be more widely used among the neurological community for learning neurosurgery. It seems clear that its benefits, such as easy accessibility and low or even no cost, outweigh its disadvantages. Although the platform offers a good design and lists tens of thousands of videos on neurosurgery, finding the good ones remains a daunting task. There is also a lack of good-quality videos covering all subdivisions of neurological surgery.

YouTube used to restrict video length to 10 minutes and, only recently, abandoned this policy. For that reason, educational departments headed to different solutions, such as Vimeo.com, which allowed longer content to be posted.

It is important to note that, nowadays, it is a lot easier to record surgeries and lectures due to technological advances in acquiring images and videos. Microscopes and endoscopes can record many kinds of surgery, such as skull base, intraventricular, or even minimally invasive spine surgeries. We can have a camera attached to our headlight, or even use smartphones to record the surgical procedure. This feature brought us a huge interchange in the video information field, which is a very important way to learn skills in neurosurgery. In this field, merely reading about the techniques in papers is not enough, and visualization of the surgery represents a fundamental upgrade. In the future, we believe that the main neurosurgery departments in the world will make their surgeries available through channels that will allow any surgeon in the world to watch and give opinions. This will foster the discussion and ultimately improve patient care.

Some scientific and education associations have created videos as part of knowledge transfer. This movement has brought about better quality videos and, consequently, better results in terms of educational impact. ${ }^{11}$ Another notable movement is the increase of medical professionals participating as publishers and viewers of YouTube videos, which can reflect an increased awareness of the importance of this new tool among this population. ${ }^{1}$

The use of YouTube and social networks in neurosurgery education can remodel teaching and learning. However, to make this happen in synchrony with other authors, ${ }^{10,12,14,15,17}$ we suggest that educational institutions collaborate and build their own YouTube channels, to produce high quality relevant material, as a first step to cover a broader area of contents rather than offer repetitive information. Primarily, the objective of this collaborative effort would to improve the learning experience of their students.

Whereas the preferred YouTube videos, or the quantity of "likes" are not indicative of video quality of videos, ${ }^{17}$ it is important to devise a tool for video evaluation to ensure a common understanding and means for quality measurement. ${ }^{13}$

Finally, videos quality is indeed an important barrier to elevate these videos to a professional training status. Nonetheless, this is a barrier that users from the medical field can surpass, as demonstrated through the YouTube channels that emerge as reliable sources of videos.

\section{References}

1 Alas A, Sajadi KP, Goldman HB, Anger JT. The rapidly increasing usefulness of social media in urogynecology. Female Pelvic Med Reconstr Surg 2013;19(4):210-213

2 Abbasi K, Butterfield M, Connor J, et al. Four futures for scientific and medical publishing. BMJ 2002;325(7378):1472-1475

3 Bridge PD, Jackson M, Robinson L. The effectiveness of streaming video on medical student learning: a case study. Med Educ Online 2009; $14: 11$

4 Kubben PL. What every neurosurgeon should know about the Web 2.0. Surg Neurol Int 2010;1:21

5 Moreau JJ, Caire F, Kalamarides M, et al. [Changing the teaching of neurosurgery with information technology]. Presse Med 2009; 38(10):1425-1433

6 Hughes MA, Brennan PM. The Internet for neurosurgeons: current resources and future challenges. Br J Neurosurg 2011;25(3): 347-351

7 Topps D, Helmer J, Ellaway R. YouTube as a platform for publishing clinical skills training videos. Acad Med 2013;88(2):192-197

8 Jaffar AA. YouTube: An emerging tool in anatomy education. Anat Sci Educ 2012;5(3):158-164

9 Farnan J, Paro JA, Higa J, Edelson J, Arora VM. The YouTube generation: implications for medical professionalism. Perspect Biol Med 2008;51(4):517-524

10 Dias-Silva D, Pimentel-Nunes P, Magalhães J, et al. The learning curve for narrow-band imaging in the diagnosis of precancerous gastric lesions by using Web-based video. Gastrointest Endosc 2014;79(6):910-920, quiz 983-e1, 983.e4 
11 Desai T, Sanghani V, Fang X, Christiano C, Ferris M. Assessing a nephrology-focused YouTube channel's potential to educate health care providers. J Nephrol 2013;26(1):81-85

12 Duncan I, Yarwood-Ross L, Haigh C. YouTube as a source of clinical skills education. Nurse Educ Today 2013;33(12):1576-1580

13 Azer SA. Can "YouTube" help students in learning surface anatomy? Surg Radiol Anat 2012;34(5):465-468

14 Raikos A, Waidyasekara P. How useful is YouTube in learning heart anatomy? Anat Sci Educ 2014;7(1):12-18

15 Rössler B, Lahner D, Schebesta K, Chiari A, Plöchl W. Medical information on the Internet: Quality assessment of lumbar punc- ture and neuroaxial block techniques on YouTube. Clin Neurol Neurosurg 2012;114(6):655-658

16 Fischer J, Geurts J, Valderrabano V, Hügle T. Educational quality of YouTube videos on knee arthrocentesis. J Clin Rheumatol 2013; 19(7):373-376

17 Camm CF, Sunderland N, Camm AJ. A quality assessment of cardiac auscultation material on YouTube. Clin Cardiol 2013;36(2):77-81

18 Gabarron E, Fernandez-Luque L, Armayones M, Lau AY. Identifying Measures Used for Assessing Quality of YouTube Videos with Patient Health Information: A Review of Current Literature. Interact J Med Res 2013;2(1):e6 